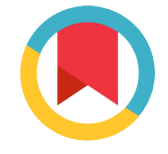

Check for updates
*For correspondence:

rafieian@yahoo.com

Competing interests: The authors declare that no competing interests exist.

Received: 18 September 2017

Accepted: 22 November 2017

Published: 29 November 2017

Copyright The Author(s) 2017. This article is published with open access by BioMedPress.

This article is distributed under the terms of the Creative Commons Attribution License (CC-BY 4.0) which permits any use, distribution, and reproduction in any medium, provided the original author(s) and the source are credited.

\section{Concise review: Medicinal plants are effective against leishmaniasis}

\section{Mahmoud Bahmani ${ }^{1}$, Naser Abbasi², Masih Hosseini ${ }^{3}$, Mahmoud Rafieian-Kopaei3,*}

\author{
${ }^{1}$ Razi Herbal Medicines Research Center, Lorestan University of Medical Sciences, \\ Khorramabad, Iran \\ ${ }^{2}$ Biotechnology and Medicinal Plants Research Center, Ilam University of Medical \\ Sciences, Ilam, Iran \\ ${ }^{3}$ Medical Plants Research Center, Basic Health Sciences Institute, Shahrekord University \\ of Medical Sciences, Shahrekord, Iran
}

\begin{abstract}
Leishmaniasis is an important zoonotic parasitic disease in tropical areas. It is a neglected disease and is a great health catastrophe in Iran. Pentavalent antimony compounds are used for its treatment, but they have adverse effects. Therefore, the use of natural herbs with low adverse effects seems necessary for treatment of Leishmaniasis. In this study, we tried to introduce the natural medicines effective against Leishmaniasis. In this review study, keywords searched included natural medicines, herbal medicines, medicinal plants, Leishmaniasis, and treatment in relevant publications published between 1990 and 2017. Searching was on databases including ISI Web of Science, PubMed, PubMed Central, Scopus, ISC, SID, Magiran and some other databases. The relevant articles were reviewed for the review study. The results showed that medicinal plants: Ferula assafoatida (with IC50 of $0.38 \mathrm{mg} / \mathrm{ml}$ ), Glycyrrhiza glabra (with IC50 of $25 \mathrm{mg} / \mathrm{ml}$ ), Allium sativum (with IC50 of $0.57 \mathrm{mg} / \mathrm{ml}$ ), Cephalis ipecacuana (with IC50 of $0.01 \mathrm{mg} / \mathrm{ml}$ ), Artemisia aucheri (with IC50 of $0.46 \mathrm{mg} / \mathrm{ml}$ ) and Eucalyptus globulus (with IC50 of 0.17 $\mathrm{mg} / \mathrm{ml}$ ) were the natural medicines effective against the disease. Compositions with di-, tri-, tetra-Sulfide, Coumarin derivatives, Camuou-nephrole, Episamarcandine, Amblipernine, Carnephrole, Azafoetidine, Froxolicin, Azafoetidinole, Saradaferine, 1, 8 Cineole, Scopodreniole, Semen, Sabinine, Cineole, Inaleole, Eojenole, Farenzole, Borneol, Allicin, acid Glycerisic, Emetine and Cephalin can have the potential to produce potent drugs against Leishmaniasis. In sum, there are some specific medicinal plants and compounds effective against Leishmaniasis which can be used per se or following changes in their formula to prepare and introduce new drags against this disease.
\end{abstract}

\section{Keywords}

Disease, Leishmaniasis, Natural medicines, Treatment 


\section{Introduction}

History of consumption of herbal drugs in treatment of diseases goes back to the first human living that has revolted and developed during centuries (Fankam Aime and Jules, 2014; Rahmatullah et al., 2013). Great tendency of people toward natural treatments, which are harmless, cost-effective, and cultural compatible, has caused extensive use of pharmaceutical plants in Iranian traditional medicine (Bahmani et al., 2016; Mahomoodally and Fawzi, 2013; Mustafa et al., 2017; Rouhi-Boroujeni et al., 2017). Although in the past half century, the use of chemical and synthetic drugs has advanced; the adverse effects of these drugs on life have caused a second trend to herbal drugs (Li et al., 2011; Sarrafchi et al., 2016; Tomlinson and Akerele, 2015). Natural substances, extracted from medicinal plants, are reliable sources of procurement of medicines and the original foundation in development of pharmaceutical compounds (Ntie-Kang et al., 2013). Herbal drugs have a better general compliance due to low adverse effects (Medagama and Bandara, 2014; Shayganni et al., 2016). Parasitic diseases infecting humans are important and serious health problems that result in significant effects on individuals and great economic and social costs (Akhoundi et al., 2013; Belkaid et al., 2002; Conceicao et al., 2016; Gutierrez et al., 2016; Mahmoudi et al., 2013; Mirzaei et al., 2013; Petitdidier et al., 2016; Sacks and Perkins, 1984; Soares et al., 2017). Various herbal drugs are used for the treatment of parasitic diseases (dos Santos Silva, 2014; Oliveira et al., 2015; Tahir et al., 1998). Leishmaniasis is an important parasitic zoonotic disease in tropical areas, and is considered a neglected disease (Ndjonka et al., 2013). Studies and statistics show that about 350 million people worldwide are at risk of being infected with the disease (WHO, 2010). Annually, approximately two million new cases of the disease are reported (Mohajery et al., 2004). Iran, Algeria, Nicaragua, Colombia, Peru, Bolivia, Afghanistan, Brazil, Syria, and Saudi Arabia are the inhabitant countries of cutaneous leishmaniasis (Gramiccia and Gradoni, 2005). Cutaneous Leishmaniasis is the most important parasitic disease in Iran and even in Middle East area (Governorate, 1985). Leishmaniasis is a great health catastrophe in Iran (Shirazi et al., 2006). In Iran, the regions like Khorasan, Yazd, Bushehr, Fars, Khuzestan, Ilam, and Esfahan have the highest rate of this disease in the country (Tabatabaei et al., 2007). Leishmaniasis imposes a great economic burden on the community in developing countries (Ashford et al., 2010). Cutaneous Leishmaniasis causes skin lesions with remaining scars. Pentavalent antimonies are used for its treatment, but have high level of adverse effects (Mohajery et al., 2004).

Therefore, using herbal drugs with natural source and low adverse effects seems necessary for the treatment of cutaneous Leishmaniasis. In this study, we introduce natural medicines against Leishmaniasis. 


\section{Methods}

In this review study, keywords searched included natural medicines, herbal medicines, medicinal plants, Leishmaniasis, and treatment. Searching was on databases including ISI Web of Science, PubMed, PubMed Central, Scopus, ISC, SID, Magiran and some other databases. The relevant articles were reviewed for this review article.

\section{Results}

The results of the literature review showed that medicinal plants, including Ferula assafoatida, Glycyrrhiza glabra, Allium sativum, Cephalis ipecacuana, Artemisia aucheri, and Eucalyptus globulus were the herbal medicines effective against the disease. The results of the present study showed that herbal plants such as Ferula assafoatida with IC50 of $0.38 \mathrm{mg} / \mathrm{ml}$, Glycyrrhiza glabra plant with IC50 of $25 \mathrm{mg} / \mathrm{ml}$, Allium sativum plant with IC50 of 0.57 of $\mathrm{mg} / \mathrm{ml}$, Cephalis ipecacuana plant with IC50 of $0.01 \mathrm{mg} / \mathrm{ml}$, Artemisia aucheri plant with IC50 of $0.46 \mathrm{mg} / \mathrm{ml}$ and Eucalyptus globulus herb with IC50 of $0.17 \mathrm{mg} / \mathrm{ml}$ were the natural medicines effective against leishmanisis (Table 1).

Table 1. The most important herbal medicines effective against Leishmaniasis with IC50 values in $\mathrm{mg} / \mathrm{ml}$

\begin{tabular}{|c|c|c|c|c|c|}
\hline Raw & Plant name & Scientific name & Family name & $\begin{array}{c}\mathrm{IC50} \\
(\mathrm{mg} / \mathrm{ml})\end{array}$ & Ref. \\
\hline 1 & Asafoetida & Ferula assafoatida & Apiaceae & 0.38 & $\begin{array}{c}\text { (Alborzi et al., } \\
\text { 2003) }\end{array}$ \\
\hline 2 & Liquorice & Glycyrrhiza glabr a & Fabaceae & 0.25 & (Chen et al., 1993) \\
\hline 3 & Garlic & Allium sativum & Liliaceae & 0.57 & $\begin{array}{c}\text { (Ghazonfari et al., } \\
2000)\end{array}$ \\
\hline 4 & Ipecacuanha & $\begin{array}{c}\text { Cephalis } \\
\text { ipecacuana }\end{array}$ & Rubiaceae & 0.01 & (Neal, 1970) \\
\hline 5 & $\begin{array}{c}\text { Greek } \\
\text { goddess Artemis }\end{array}$ & Artemisia aucheri & Asteraceae & 0.46 & (Sharif et al., 2006) \\
\hline 6 & $\begin{array}{l}\text { Tasmanian } \\
\text { bluegum }\end{array}$ & $\begin{array}{l}\text { Eucalyptus } \\
\text { globulus }\end{array}$ & Myrtaceae & 0.17 & (Tahir et al., 1998) \\
\hline
\end{tabular}




\section{Discussion}

In this study, it was found that herbal medicines, including Ferula assafoatida, Glycyrrhiza glabra, Allium sativum, Cephalis ipecacuana, Artemisia aucheri and Eucalyptus globulus were medicinal plants effective against Leishmaniasis. In traditional medicine, Asafoetida plant is used against seizures, worms, neural diseases, intestinal dysmotility, renal pain, rheumatism, muscular clench, and hypertension, and for elimination of fatty foods' harms, as well as for enhancing appetite and memory (Lee et al., 2009; Leung, 1996; Mohammadi, 2009; Sadraei et al., 2003). Asafoetida has di-, tri-, and tetra-sulfide, coumarin derivatives, camuonephrole, episamarcandine, amblipernine, carnephrole, azafoetidine, froxolicin, azafoetidinole, saradaferine, and foetidine (Abd El-Razek et al., 2001; Bandyopadhyay, 2006; Banerji et al., 1998; Fraga, 1999; Kajimoto et al., 1989; Kojima et al., 2000; Nassar et al., 1995). Eucalyptus has antibacterial, antifungal, antioxidan, anti-infectious, and antispasmatic effects. It is also fever palliative and putative, hypoglycemic and anthelmintic plant (Ministry of health and medical education, 2004; Zargary, 1996). Eucalyptus plant contains a compound called 1, and 8 cineole or Eucalyptole that is the main composition of this plant (Mulyaningsih et al., 2010; Oyedeji et al., 1996). Artemisia has astringent property, disinfectant activity, antimicrobial, antiparasite, anti-poisoning, and anti-insect effects (AliAbadi et al., 2010; AzadBakht, 2003). Artemisia contains scopodreniole, semen, sabinine, cineole, inaleole, eojenole, farenzole, and borneol (AliAbadi et al., 2010; AzadBakht, 2003). Garlic has cardiovascular effects, prevents cancer, has antidiabetic effects, and anti-microbial activity. The main active ingredient of this plant is called allicin (Heinrich and Larry, 1996; Leistner and Gorris, 1995). Licorice is used to treat bloating, respiratory infections, peptic ulcers and gastritis. It is also used as antitussive, anti-hepatitis, and anti-tumor agent (Baba and Shigeta, 1993; Lentihet and Nygren, 1997; Sato et al., 1996; Li et al., 2011; Haraguchi et al., 1998; Csuk et al., 2010; Fukai et al., 2002). The major component of licorice is glycerisic acid (Alan Teck et al., 2007; Mehravar, 1991; Marzi et al., 1993). Cephalis ipecacuana is used in the treatment of cough, children's bronchitis, and amoebic diarrhea. This plant has active compounds including emetine, and cephaline (Vetrichelvan et al., 1996).

Asafoetida plant with compositions such as di-, tri-, tetra-Sulfide, coumarin derivatives, camuonephrole, episamarcandine, amblipernine, carnephrole, azafoetidine, froxolicin, azafoetidinole, saradaferine, 1, 8 cineole, scopodreniole, semen, sabinine, cineole, inaleole, eojenole, farenzole, borneol, allicin, acid glycerisic, emetine and cephalin has the potential for production of potent drugs against Leishmaniasis.

Other compounds of these plants may also be involved in anti-leishmania activities of these plants. Phenolic compounds are a group of compounds which have been shown to be effective against a wide variety of microbial infections as well as other diseases (Hosseinzadeh et al., 2015; Lorigooini et al., 2014; Lorigooini et al., 2015; Ghasemi and Lorigooini, 2016). They should be examined for treatment of Leishmaniasis and for preparation of new drugs. 


\section{Conclusion}

There are some specific medicinal plants or compounds effective against Leishmaniasis which can be used per se or following changes in their formula to prepare and introduce new drags against Leishmaniasis.

\section{Abbreviations}

IC50 $=$ The half maximal inhibitory concentration

\section{Acknowledgements}

The authors would like to express their gratitude for financial support of the Research and Technology Deputy of Shahrekord University of Medical Sciences, Shahrekord, Iran.

\section{Author Contribution}

All authors contributed to the design of the research. MB, NA, MH and MRK collected the data. MRK write, edited and revised it. All authors reviewed and commented on final draft

\section{References}

Abd El-Razek, M. H., Ohta, S., Ahmed, A. A., \& Hirata, T. (2001). Sesquiterpene coumarins from the roots of Ferula assa-foetida. Phytochemistry, 58(8), 1289-1295. https://doi.org/10.1016/S0031-9422(01)00324-7

Akhoundi, M., Mohebali, M., Asadi, M., Mahmodi, M. R., Amraei, K., \& Mirzaei, A. (2013). Molecular characterization of Leishmania spp. in reservoir hosts in endemic foci of zoonotic cutaneous leishmaniasis in Iran. Folia Parasitologica, 60(3), 218-224. https:// doi.org/10.14411/fp.2013.024

Alan Teck, W. E. (2007). Evaluation of surfactant assisted pressurized liquid extraction for the determination of glycyrrhizin and ephedrine in medicinal plants. Analytica Chimica Acta, 583(2), 289-295. https://doi.org/10.1016/j.aca.2006.09.019

Alborzi, A., Namjoian, F., Azadbakht, M., Obodi, B., Panjehshahin, M., Rasoli, M., . . . (2003). Effects of Ferula assa-foetida and its effective fractions on Leishmania (in vitro). Infect Tropic Dis Iran, 8(12), 36-40.

AliAbadi, H., Nasri, M. and Mirshekari, B. (2010). Effect of Nitrogen Fertilizer and method for its consumption of qualitative and quantitative performance of Artemisia. Journal of Crop Ecophysiology, 2(3), 68-175. 
Amman Governorate. Parasitology. (1985). Am J Trop Med Hyg, 79, 13-46.

Ashford, R. W., Bern, C., Boelaert, M., Bryceson, A., Chappuis, F., Croft, S., . . .. (2010). Leishmaniasis control. World Health Organization.

AzadBakht, M., Ziaaei, Abdollahi, F. and Shaabankhani, B. (2003). Effect of plant essential oils of Artemisia aucheri, Thymus vulgaris and Myrtus communis on Trichomonas vaginalis. Journal of Medicinal Plant, 8, 34-40.

Baba, M., \& Shigeta, S. (1993). Antiviral activity glycyrrhizin against varicella zoster virus in vitro. Mund-, Kiefer- und Gesichtschirurgie, 3(1), 30-33.

Bahmani, M., Sarrafchi, A., Shirzad, H., \& Rafieian-Kopaei, M. (2016). Autism: Pathophysiology and promising herbal remedies. Current Pharmaceutical Design, 22(3), 277-285. https://doi.org/10.2174/1381612822666151112151529

Bandyopadhyay, D., Basak, B., Chatterjee, A., Lai, T.K., Banerji, A., Banerji, J., Neuman, A. and Prange, T. (2006). Saradaferin, a new sesquiterpenoid coumarin from Ferula assa foetida. Natural product Res, 20 (10), 961: 965.

Banerji, A., Mallick, B., Chatterjee, A., Budzikiewicz, H., \& Breuer, M. (1998). Assafoetidin and ferocolicin, two sesquiterpenoid coumarins from Ferula assafoetida Regel. Tetrahedron, 29(13), 1557-1560. https://doi.org/10.1016/S0040-4039(00)80351-2

Belkaid, Y., Piccirillo, C. A., Mendez, S., Shevach, E. M., \& Sacks, D. L. (2002). CD4+ CD25+ regulatory $T$ cells control Leishmania major persistence and immunity. Nature, 420(6915), 502-507. https://doi.org/10.1038/nature01152

Chen, M., Christensen, S. B., Blom, J., Lemmich, E., Nadelmann, L., Fich, K., . . . Lichochalcone, A. (1993). A novel antiparasitic agent with potent activity against human pathogenic protozoan species of leishmania. Antimicrobial Agents and Chemotherapy, 37(12), 2550-2556. https://doi.org/10.1128/AAC.37.12.2550

Conceição, J., Davis, R., Carneiro, P. P., Giudice, A., Muniz, A. C., Wilson, M. E., . . . Bacellar, O. (2016). Characterization of neutrophil function in human cutaneous leishmaniasis caused by Leishmania braziliensis. PLoS Neglected Tropical Diseases, 10(5), e0004715. https://doi.org/10.1371/journal.pntd.0004715

Csuk, R., Schwarz, S., Kluge, R., \& Ströhl, D. (2010). Synthesis and biological activity of some anti tumora active deraiveties from glycyrrhetic acid. European Journal of Medicinal Chemistry, 45(12), 5718-5723. https://doi.org/10.1016/j.ejmech.2010.09.028

dos Santos Silva, F., . . .. (2014). An ethnopharmacological assessment of the use of plants against parasitic diseases in humans and animals. Journal of Ethnopharmacology, 155(2), 1332-1341. https://doi.org/10.1016/j.jep.2014.07.036

Fankam Aimé, G., \& Jules, R. (2014). Antibacterial activities of Beilschmiedia obscura and six other Cameroonian medicinal plants against multi-drug resistant Gram-negative phenotypes. BMC Complementary and Alternative Medicine, 14(1), 241. https://doi.org/ 10.1186/1472-6882-14-241

Feasey, N., Wansbrough-Jones, M., Mabey, D. C., \& Solomon, A. W. (2010). Neglected tropical diseases. British Medical Bulletin, 93(1), 179-200. https://doi.org/10.1093/bmb/ Idp046

Fraga, B. M. (1999). Natural sesquiterpenoids. Natural Product Reports, 16(6), 711-730. https://doi.org/10.1039/a804633f

Fukai, T., Marumoa, A., Kaitou, K., Kanda, T., Terada, S., \& Nomura, T. (2002). AntiHelicobacter pylori flavonoids from licorice extract. Life Sciences, 71(12), 1449-1463. https://doi.org/10.1016/S0024-3205(02)01864-7 
Ghasemi, S., \& Lorigooini, Z. (2016). A review of significant molecular mechanisms of flavonoids in prevention of prostate cancer. Journal of Chemical and Pharmaceutical Sciences, 9, 3388-3394.

Ghazonfari, T., Hassani, Z. M., Ebtekar, M., Ahmadiani, A., Naderi, G., \& Azar, A. (2000). Garlic induces a shift in a Leishmania major - infected balby mice. Scandinavian Journal of Immunology, 52, 491-495. https://doi.org/10.1046/j.1365-3083.2000.00803.x

Gramiccia, M., \& Gradoni, L. (2005). The current status of zoonotic leishmaniases and approaches to disease control. International Journal for Parasitology, 35(11-12), 11691180. https://doi.org/10.1016/j.ijpara.2005.07.001

Gutiérrez, V., Seabra, A. B., Reguera, R. M., Khandare, J., \& Calderón, M. (2016). New approaches from nanomedicine for treating leishmaniasis. Chemical Society Reviews, 45(1), 152-168. https://doi.org/10.1039/C5CS00674K

Haraguchi, H., Tanimoto, K., Tamura, Y., Mizutani, K., \& Kinoshita, T. (1998). Mode of antibacterial action of retrochalcones from Glycyrrhiza inflate. Phytochemistry, 48(1), 125-129. https://doi.org/10.1016/S0031-9422(97)01105-9

Heinrich, P., Larry, D.L, editors. (1996). Garlic: The science and therapeutic application of Allium Sativum L. and related species. 2 nd ed. Translated to English by: William W.

Hosseinzadeh, B., Khoshtaghaza, M., Loriooini, Z., Minaei, S., \& Zareiforoush, H. (2015). Analysis of the combinative effect of ultrasound and microwave power on Saccharomyces cerevisiae in orange juice processing. Innovative Food Science \& Emerging Technologies, 32, 110-115. https://doi.org/10.1016/j.ifset.2015.09.015

Kajimoto, T., Yahiro, K., \& Nohara, T. (1989). Sesquiterpenoid and disulphide derivatives from ferula assa-foetida. Phytochemistry, 28(6), 1761-1763. https://doi.org/10.1016/ S0031-9422(00)97841-5

Khalid, Sami A., et al. (2016). The potential antileishmanial activity of some Sudanese medicinal plants.

Kojima, K. K., Isaka, P., Ondognii, O., Zevgeegiin, O., Gombosurengyin, P., Davgiin, K., . . . Ogihara, Y. (2000). Sesquiterpenoid derivatives from Ferula ferulaeoides. Chemical \& Pharmaceutical Bulletin, 48(3), 353-356. https://doi.org/10.1248/cpb.48.353

Lee, C. L., Chiang, L. C., Cheng, L. H., Liaw, C. C., Abd El-Razek, M. H., Chang, F. R., \& Wu, Y. C. (2009). Influenza a (H1N1) antiviral and cytotoxic agents from Ferula assafoetida. Journal of Natural Products, 30(20), 1568-1572. https://doi.org/10.1021/ np900158f

Leistner, L., \& Gorris, L. (1995). Food preservation by hurdle technology. Food Science and Technology (Campinas), 6(2), 41-46. https://doi.org/10.1016/ S0924-2244(00)88941-4

Lentihet, M., \& Nygren, A. (1997). Licorice an old drug and currently a candy with metabolic effects. Journal of Oral Pathology \& Medicine, 26(1), 36-39.

Leung, AY., Foster, S. (1996). Encyclopedia of common natural ingredient used in food, drugs and cosmetics. 2nd ed. John willy \& sons, inc. new York, 44-5.

Li, Thomas SC. (2016). Chinese \& Related North American Herbs: Phytopharmacology \& Therapeutic Values. CRC press.

Li, Y. J., Chen, J., Li, Y., Li, Q., Zheng, Y. F., Fu, Y., \& Li, P. (2011). Screeing and haracterization of natural antioxidants in four Glycyrrhiza species by liquid chromatography coupied with electrospray ionization quadrupole time of flight tanden 
mass spectrometry. Journal of Chromatography. A, 1218(45), 8181-8191. https:// doi.org/10.1016/j.chroma.2011.09.030

Lorigooini, Z., Ayatollahi, S. A., Amidi, S., \& Kobarfard, F. (2015). Evaluation of antiplatelet aggregation effect of some Allium species. Iranian journal of pharmaceutical research. IJPR, 14(4), 1225.

Lorigooini, Z., Kobarfard, F., \& Ayatollahi, S. A. (2014). Anti-platelet aggregation assay and chemical composition of essential oil from Allium atroviolaceum Boiss growing in Iran. International Journal of Biosciences. IJB, 5(2), 151-156. https://doi.org/10.12692/ ijb/5.2.151-156

Mahmoudi, M.-R., Kazemi, B., Mohammadiha, A., Mirzaei, A., \& Karanis, P. (2013). Detection of Cryptosporidium and Giardia (oo)cysts by IFA, PCR and LAMP in surface water from Rasht, Iran. Transactions of the Royal Society of Tropical Medicine and Hygiene, 107(8), 511-517. https://doi.org/10.1093/trstmh/trt042

Mahomoodally, M., \& Fawzi, F. (2013). Traditional medicines in Africa: An appraisal of ten potent African medicinal plants. Evidence-Based Complementary and Alternative Medicine, 2013, 1-14. https://doi.org/10.1155/2013/617459

Marzi, V., Circella, G., \& Vampa, G. M. (1993). Effect of soil depth on the rooting system growth in Glycyrrhiza glabra L. ISHS. Acta Horticulturae, (331): 71-78. https://doi.org/ 10.17660/ActaHortic.1993.331.10

Medagama, A. B., \& Bandara, R. (2014). The use of Complementary and Alternative Medicines (CAMs) in the treatment of diabetes mellitus: Is continued use safe and effective? Nutrition Journal, 13(1), 102. https://doi.org/10.1186/1475-2891-13-102

Mehravar, M. (1991). Extraction of licorice from licorice roots by pure water and one percent aqueous ammonia solution. M.Sc. Thesis. Shiraz University, Shiraz, Iran, 107.

Ministry of health and medical education. (2004). Iran herbal farmacoope, 84-93.

Mirzaei, A., Rouhani, S., Kazerooni, P. A., Farahmand, M., \& Parvizi, P. (2013). Molecular detection and conventional identification of Leishmania species in reservoir hosts of zoonotic cutaneous Leishmaniasis in Fars province. South of Iran. Iranian Journal of Parasitology, 8(2), 280-288.

Mohajeri M, Shamsian A. (2010). Medical protozoology. 2nd ed. Mashhad: Academic Center for Education, Culture and Research (ACECR) Publishers.

Mohajery, M., Hatam, G. R., Shamsian, A. A., \& Javaheri, A. (2004). Isoenzyme identification Of L.Major. Journal of Medicine, 47, 19-27.

Mohammadi, R, Shokouh Amiri, M., Sepahvand, A., Roodbar Mohammadi, S., ShadziSh, Mirsafaei H. and Noor Shargh, R. (2009). Antifungal activity of Ferula assa - foetida against clinical agents of Mucormycosis. Majallah-i Danishkadah-i Pizishki-i Isfahan, 27(100), 582-587.

Mulyaningsih, S., Sporer, F., Zimmermann, S., Reichling, J., \& Wink, M. (2010). Synergistic properties of the terpenoids aromadendrene and 1,8-cineole from the essential oil of Eucalyptus globulus against antibiotic-susceptible and antibioticresistant pathogens. Phytomedicine, 17(13), 1061-1066. https://doi.org/10.1016/j.phymed.2010.06.018

Mustafa, G. H., Arif, R., Atta, A., Sharif, S., \& Jamil, A. (2017). Bioactive compounds from medicinal plants and their importance in drug discovery in Pakistan. Matrix Science Pharma, 1(1), 17-26. https://doi.org/10.26480/msp.01.2017.17.26

Nassar, M. I., Abu-Mustafa, E. A., \& Ahmed, A. A. (1995). Sesquiterpene coumarins from Ferula assafoetida L. Die Pharmazie, 50(11), 766-767. 
Ndjonka, D., Rapado, L., Silber, A., Liebau, E., \& Wrenger, C. (2013). Natural products as a source for treating neglected parasitic diseases. International Journal of Molecular Sciences, 14(2), 3395-3439. https://doi.org/10.3390/ijms14023395

Neal, R. A. (1970). Effect of emetine and related compounds on experimental cutaneous leishmaniasis. Annals of Tropical Medicine and Parasitology, 64(2), 159-165. https:// doi.org/10.1080/00034983.1970.11686677

Ntie-Kang, F., Lifongo, L. L., Mbaze, L. M., Ekwelle, N., Owono Owono, L. C., Megnassan, E., . . Efange, S. M. N. (2013). Cameroonian medicinal plants: A bioactivity versus ethnobotanical survey and chemotaxonomic classification. BMC Complementary and Alternative Medicine, 13(1), 147. https://doi.org/10.1186/1472-6882-13-147

Oliveira, D. R., Krettli, A. U., Aguiar, A. C. C., Leitão, G. G., Vieira, M. N., Martins, K. S., \& Leitão, S. G. (2015). Ethnopharmacological evaluation of medicinal plants used against malaria by quilombola communities from Oriximiná, Brazil. Journal of Ethnopharmacology, 173, 424-434. https://doi.org/10.1016/j.jep.2015.07.035

Oyedeji, A., Ekundayo, O., Olawore, O., Adeniyi, B., \& Koenig, W. (1996). Antimicrobial activity of the essential oils of five Eucalyptus species growing in Nigeria. Fitoterapia, 70(5), 526-528. https://doi.org/10.1016/S0367-326X(99)00083-0

Petitdidier, E., Pagniez, J., Papierok, G., Vincendeau, P., Lemesre, J.-L., \& BrasGonçalves, R. (2016). Recombinant forms of Leishmania amazonensis excreted/secreted promastigote surface antigen (PSA) induce protective immune responses in dogs. PLoS Neglected Tropical Diseases, 10(5), e0004614. https://doi.org/10.1371/journal.pntd. 0004614

Rahmatullah, M., Pk, S. R., Al-Imran, M., \& Jahan, R. (2013). The Khasia tribe of Sylhet district, Bangladesh, and their fast-disappearing knowledge of medicinal plants. Journal of Alternative and Complementary Medicine (New York, N.Y.), 19(7), 599-606. https:// doi.org/10.1089/acm.2012.0254

Rouhi-Boroujeni, H., Heidarian, E., Rouhi-Boroujeni, H., Deris, F., \& Rafieian-Kopaei, M. (2017). Medicinal Plants with multiple effects on cardiovascular diseases: A systematic review. Current Pharmaceutical Design, 23(7), 999-1015. https://doi.org/ 10.2174/1381612822666161021160524

Sacks, D. L., \& Perkins, P. V. (1984). Identification of an infective state of Leishmania promastigotes. Science, 223(4643), 1417-1420. https://doi.org/10.1126/science. $\underline{6701528}$

Sadraei, H., Ghannadi, A., \& Malekshahi, K. (2003). Composition of the essential oil of assa foetida and its spasmolytic action. Saudi Pharmaceutical Journal, 11(3), 136-140.

Sarrafchi, A., Bahmani, M., Shirzad, H., \& Rafieian-Kopaei, M. (2016). Oxidative stress and Parkinson's disease: New, hopes in treatment with herbal antioxidants. Current Pharmaceutical Design, 22(2), 238-246. https://doi.org/ 10.2174/1381612822666151112151653

Sato, H., Goto, W., Yamamura, J., Kurokawa, M., Kageyama, S., Takahara, T., . . Shirak, K. (1996). Therapeutic basis of glycyrrhizin on chronic hepatitis B. Antiviral Research, 30(2-3), 171-177. https://doi.org/10.1016/0166-3542(96)00942-4

Sharif, M., Ziaei, H., Azadbakht, M., Daryani, A., Ebadattalb, A., \& Rostami, M. (2006). Effeet of methanolic extract of Artemisia auchori and Camellia sinansis on Leishmania major (in vitro). Turk Sci, 36(6), 365-369. 
Shayganni, E., Bahmani, M., Asgary, S., \& Rafieian-Kopaei, M. (2016). Inflammaging and cardiovascular disease: Management by medicinal plants. Phytomedicine, 23(11), 11191126. https://doi.org/10.1016/j.phymed.2015.11.004

Shirazi, M., Ranjbar, R., \& Khansari, K. (2006). Secondary bacterial infections of skin lesions suspicious for cutaneous leishmaniasis. Iranian Journal of Infectious Diseases and Tropical Medicine, 12(38), 55-58.

Soares, R. R., Antinarelli, L. M. R., Abramo, C., Macedo, G. C., Coimbra, E. S., \& Scopel, K. K. G. (2017). What do we know about the role of regulatory B cells (Breg) during the course of infection of two major parasitic diseases, malaria and leishmaniasis? Pathogens and Global Health, 111(3), 107-115. https://doi.org/10.1080/20477724.2017.1308902

Tabatabaei, S., Zahraei, M., Ahmadnia, H., Ghotbi, M., \& Rahimi, F. (2007). Principles of disease prevention and surveillance (2nd ed.). Tehran: Roohe Ghalam Publishers.

Tahir, A. E., Ibrahim, A. M., Satti, G. M. H., Theander, T. G., Kharazmi, A., \& Khslid, A. S. (1998). The potential antileishmanial activity of some Sudanse medicinal plants. Phytotherapy Research, 12(8), 576-579. https://doi.org/10.1002/ (SICI)1099-1573(199812)12:8<576::AID-PTR354>3.0.CO;2-\#

Tomlinson, T. R., \& Akerele, O. (Eds.). (2015). Medicinal plants: their role in health and biodiversity. University of Pennsylvania press.

Vetrichelvan, T., Kavimani, S., Elango, R., \& Jaykar, B. (1996). Effect of I-dopa and Imethionine supplementation on bioproduction of ementine in callus cultures of cephaelis ipecacuanha. Ancient Science of Life, 16(1), 74-78.

World Health Organization. Geneva: WHO; 2010. Packages of Interventions. 2010; Available at: http://www.who.int/whr/1996/media_centre/executive_summary1/en/ index9.html

Zargary, A. (1996). Herbal druges.Vol2. 6th edit. Univearcity publication.,312. 